Teologie kroniek: Godsbeelde van die Ou Testament: Jahwe - liefdevolle vader en moeder

\title{
Theology chronicle: Images of God in the Old Testament: Yahweh - loving father and mother
}

A Groenewald

(Universiteit van Pretoria)

ABSTRACT

Theology chronicle: Images of God in the Old Testament: Yahweh - loving father and mother

This theology chronicle proceeds from the Marcionite idea of the cruel God of the Old Testament. This idea today is still well and alive with church members, and even with students of Biblical Studies and Theology. The author then takes the reader on a short journey through some of the most sublime love texts in the Old Testament, portraying Yahweh (the God of Israel) as a loving father and even as a loving mother/wife. The article concludes with an appeal towards the reader to once again discover the beauty of the Old Testament as well as Old Testament texts.

\section{INLEIDING}

Die Christendom kan slegs in afhanklikheid van die Judaïsme verstaan word (Zenger 1994:7; 1997b:184vv) ${ }^{1}$. Dit word duidelik uit

1 In hierdie verband kan daar verwys word na die volgende aanhaling van Rendtorff (1995:97): "Das wichtigste theologische Ereignis der zweiten Hälfte dieses Jahrhunderts ist die Entdeckung des Judentums für die christliche Theologie". Vgl verder ook Zenger (2004:12): "Ohne Heilige Schrift gibt es kein Christentum. Die christlichen Gemeinden haben im Gottesdienst von Anfang an biblische Texte als Gottes Wort vorgelesen und ausgelegt. Biblische Texte waren normativ und formativ für christliche Existenz in der Nachfolge Jesu. Sprache und Bilder der Bibel bildeten die kulturelle Matrix der ersten Jüngerinnen und Jünger Jesu. Diese Bibel der Christen war bis ins 2. Jh. hinein die Bibel Israels". Gunneweg (1977:9) sluit ook hierby aan wanneer hy soos volg opmerk: "Das Alte Testament ist eine Sammlung israelitischer und jüdischer Schriften. Diese Schriften sind die religiöse Nationalliteratur des israelitischen Volkes und das heilige Buch der jüdischen Gemeinde, der Synagoge. Sie sind zweifelsohne und fraglos nicht christlichen Ursprungs, sondern älter als das Christentum. Auch ihre Sammlung zu einem Kanon heiliger, unantastbarer - sakrosankter - und, wie gelehrt wurde, göttlich inspirierter Schriften ist nicht zuerst das Werk der christlichen Kirche gewesen. 
die lees van byna elke bladsy in die Nuwe Testament. Ten einde die boodskap van God se werking deur middel van Jesus van Nasaret te verstaan, te verduidelik, asook by die lesers tuis te bring, word daar voortdurend na die "Geskrifte van Israel" verwys en, sonder om moeg te word, daaruit siteer. Deur middel van "volgens die Skrifte", en "soos daar geskrywe staan", verleen die Nuwe-Testamentiese Geskrifte outoriteit en legitimiteit aan sigself. Hierin het die vroeë Kerk ook die Nuwe Testament gevolg ${ }^{2}$.

Dit het veral duidelik geword in die eerste helfte van die tweede eeu toe Marcion, die seun van 'n biskop uit Klein-Asië, " $n$ grootskaalse poging aangewend het om die Christendom te suiwer van sy Joodse wortels (Zenger 1994:7, vgl ook Den Heyer 1995:19v; Gunneweg 1977:8 en Le Roux 2003:124vv) ${ }^{3}$. Marcion se hoofbeswaar kom in kort daarop neer dat, volgens hom, die Ou Testament vir die Christen geen waarde sou hê nie. Sy beswaar is geleë in die feit dat die God van die Ou Testament (of " $n$ mens kan ook sê: die God van Israel, die Joodse God) gesien word as ' $n$ wrede God, ' $n$ God van wraak en geweld ${ }^{4}$. Hy sou wou sien dat die boodskap van

Sammlung und Abschlu $\beta$ des hebräischen Kanons waren das Werk der Synagoge um 100 n.Chr., und zwar einer Synagoge, welche stark von der pharisäischen Richtung jüdischer Theologie geprägt war". Vgl verder ook Gese 1995:35vv; Lohfink 1995:71vv; Reventlow 1995:115vv; Seebass 1995:131vv; Zenger 1995b:143vv.

2 Kaiser (1995:45) postuleer soos volg: "Wenn das Alte Testament Teil der christlichen Bibel geworden ist, so hat das seinen unbestreitbaren Grund darin, da $\beta$ Jesus und seine Jünger Juden gewesen sind und demgemä $\beta$ die jüdische Bibel fraglos als ihre heilige Schrift betrachteten".

3 Zenger (2004:12) merk soos volg op in hierdie verband: “... doch hat die Kirche dieser »Entjudaisierung « ihrer Bibel widersprochen, wohl wissend, dass die Bibel Israels das Fundament der Gottesbotschaft Jesu und des Bekenntnisses zu Jesus dem Christus ist". Vgl verder ook Zenger 1995a:17vv.

4 Vgl Le Roux (2003:129): "Wanneer die god van die Ou Testament met die goeie God vergelyk word, blyk sy radikale andersheid. Hy was 'n god van geregtigheid volgens die wet. Alles moes volgens sy wil geskied. Soos 'n tipiese antieke despoot moes sy wette in die Ou Testament streng nagekom word". Verder: "daar het dus volgens Marcion 'n onoorbrugbare kloof tussen die god van die Ou Testament en die Vader van Jesus bestaan. Jesus het gekom om die gelowige van die Ou-Testamentiese god te verlos en daarom wou Marcion niks met die Ou Testament te make gehad het nie" (Le Roux 2003:130). 
Jesus van Nasaret - naamlik 'n boodskap van die God van liefde en barmhartigheid - ontkoppel moes word van hierdie wrede Ou-Testamentiese God $^{5}$. Die Vroeë Kerk het egter kategories Marcion se idees verwerp (Le Roux 2003:132). Hierdie besluit is 'n duidelike teken dat hulle instinktief aangevoel het dat die afwysing van die $\mathrm{Ou}$ Testament vanselfsprekend ' $\mathrm{n}$ afwysing van die fondament waarop hulle staan, sou beteken het ${ }^{6}$.

Heelwat Christene (selfs nog studente in die Bybelkunde en Teologie) koester nog altyd hierdie Marcionitiese idee van die wrede God van die $\mathrm{Ou}$ Testament. Vir sommige is dit ' $\mathrm{n}$ onuitspreekbare voorbehoud teen die $\mathrm{Ou}$ Testament. Ander erken prontuit dat dit hulle persepsie van die Ou Testament is. Hierteenoor moet ' $\mathrm{n}$ mens erken dat ' $n$ dieper omgang met en intensiewer studie van die tekste van die Hebreeuse Bybel ' $\mathrm{n}$ mens tot ander insigte kan bring (Le Roux 2003:134). Die Hebreeuse Bybel bevat 'n legio tekste wat

$5 \quad$ Von Harnack (1996:31-33) formuleer Marcion se siening oor die $\mathrm{Ou}$ Testament en die Ou-Testamentiese boeke soos volg: "Auch aus ihnen blickt, nur verlarvt, das schreckliche Antlitz des grausamen Judengottes und Weltschöpfers ... so kann er damit nur die zwei großen göttlichen Autores meinen, den ATlichen Gott, der ausschließlich Wertloses und Schlimmes schafft, und den Vater Jesu Christi, der ausschließlich Gutes hervorbringt ... so mußte ihm der Judengott samt seiner Urkunde, dem AT, zum eigentlichen Feinde werden".

$6 \quad$ Vgl in hierdie verband ook Zenger (2004:13): "Dass die Kirche die Bibel Israels so in ihrer Bibel beibehielt, entsprach den in den neutestamentlichen Schriften selbst und in den wichtigen Glaubensbekenntnissen der alten Kirche sich aussprechenden Überzeugung, dass die Bibel Israels das unaufgebbare Fundament des Christentums ist ... Christliche Identität gibt es nur ... in der bleibenden Rückbindung an das Judentum als seine Wurzel und insbesondere an die Bibel Israels". Vgl ook Den Heyer (1995:20): "Uitgaande van een radicale tegenstelling tussen 'wet' en 'evangelie' concludeerde Marcion dat Jezus Christus onmogelijk gezonden kon zijn door de God van het Oude Testament. In Jezus' woorden en daden meende hij een vreemde, tot dan toe onbekende God te ontmoeten; een God, die anders dan de God van het Oude Testament, barmhartigheid, liefde en genade laat prevaleren boven straf, gerechtigheid en wraak. De God van het Oude Testament was de schepper van de aarde. Hij heeft zijn stempel gedrukt op de verhalen in de oudtestamentisch geschriften. Ze zijn dikwijls bloeddorstig en gruwelijk. Ze geven de werkelijkheid weer, maar ze bieden geen perspectief op vernieuwing en verlossing. In de Niewe Testament heerst een andere sfeer. Op een totaal nieuwe manier, door een niet eerder verkondigde genade, een niet eerder gehoord wonder, wordt de mens verlost". 
getuig van die liefde van die Jahwe (= die God van Israel) vir die mens(e). Hierdie bydrae fokus vervolgens kortliks ${ }^{7}$ op twee aspekte wat na vore kom in die Godsbeeld(e) van oud-Israel, naamlik God as vader en as moeder (vrou). In die lees van hierdie beelde word ons oorspoel deur die liefde wat Jahwe aan sy volk betoon.

Ons moet erken dat die mens nie anders kan as om sy/haar werklikheid deur middel van taal te betree nie (Vorster 2003:4vv). Wanneer die mens sy/haar werklikheid tegemoet tree, dan kan dit nie anders as in die taalkonstruksies van die spesifieke gemeenskap nie. By geboorte word elke mens in 'n taal gebore, dit wil sê in die diskoerspraktyke wat daardie gemeenskap aan hom/haar verskaf. Anders gestel: die gemeenskap skryf haar taalmatige, haar simboliese patrone op die mens se lyf. Die Ou-Testamentiese skrywer(s) kon dus nie anders as om Jahwe (= die God van Israel) uit te beeld met behulp van menslike taal en taalkonstruksies (beelde en simbole) nie. Dit was die enigste medium waaroor hulle beskik het om uitdrukking te gee aan hulle ervarings van die goddelike (transendente) en verhewe ervaring(s).

\section{JAHWE AS VADER}

Gegewe die feit dat die Hebreeuse Bybel binne 'n patriargale ${ }^{8}$ kultuur ontstaan het, is daar geen twyfel aan die feit dat die geslagtelike aard van die God van Israel (Jahwe) manlik is nie

7 Sonder om enigsins aanspraak te mak op volledigheid - plek en ruimte sal dit nie toelaat nie.

8 Wat betref die begrip "patriargaat" postuleer Schottroff, Schroer \& Wacker (1998:51) soos volg: "De analytische betekenis van dit begrip kan het best begrepen worden door het allereerst in zijn oorspronkelijke, historische context te plaatsen. Patriarchaat, sinds Aristoteles een rechtsbegrip of politieke notie, betekent de concrete heerschappij van de pater familias over zijn huishouding, niet alleen over zijn lijfelijke familie (vrouw en kinderen), maar ook over die loonarbeiders en slaven. Hiermee is tegelijk de economische component van het begrip aangeduid oftewel de maatschappelijke werkelijkheid waarop het betrekking heeft. Implicaties van deze sociaal-economische huisstructuur zijn ondermeer dat politieke en juridische zeggenschap uitsluitend aan de pater familias is voorbehouden, en dus het gehele staatswezen in die letterlijke zin van het woord patri-archaal is. In zoverre dergelijke structuren niet alleen kenmerkend zijn voor Griekenland en Rome, kan het begrip ook in een algemene zin gebruikt word als aanduiding voor de 'heerschappij van vaders', die resulteert in een juridische, politieke en economische afhankelijkheid van vrouwen, kinderen en onvrijen". 
(Klopper 2002:422; vgl ook Haag \& Elliger 1999:36). Die Ou Testament is deur mans aan mans geskryf, en wanneer God ter sprake is, is dit vanuit manlike perspektief gedoen. So dra hierdie God dan ook kenmerke wat vir mans gegeld het. God word deurentyd as "aktief" gesien - Hy is die handelende Een, die Een wat genereer, skep, oorlog voer en ingryp in krisisse. Hy word ook uitgebeeld as koning, regter en herder (Klopper 2002:423).

Volgens antropomorfiese ${ }^{9}$ taalgebruik beskik Jahwe oor 'n arm, regterhand, rug, gesig, ore, oë, mond en voete. Hy kry dus 'n liggaam, besit 'n liggaam en beskik oor 'n liggaam - net soos die mens (Staubli \& Schroer 2001:34vv). Jahwe word ook nog met ander menslike voorstellings beskryf. Hy word verder ook voorgestel as ' $n$ liefdevolle vader wat sy kinders (Israel) met liefde versorg en onderhou. Die verhouding wat daar bestaan tussen Israel en Jahwe word as 'n vader-kind verhouding uitgebeeld (vgl oa Deut $14: 1 ;^{10}$ Jes $1: 2 ;^{11}$ Hos $\left.11: 1^{12}\right)$. Enkele voorbeelde word verder hier genoem. In Jesaja $1: 2^{13}$ en Jeremia $31: 9^{14}$ word duidelik gestel dat

9 Antropomorfisme: 'n Voorstelling van God/die gode in terme van die menslike anatomie en menslike gedrag, bv deur die gebruikmaking van uitdrukkings soos "God se vingers", die "gesig van God" of die "gode was kwaad".

10 Met betrekking tot hierdie Deuteronomium-teks, konkludeer Wolff (1976:255) soos volg: "Diese enge Zugehörigkeit, die Israel als Jahwes persönliches Eigentum und 'heiliges Volk' meint, verbindet dann auch die deuteronomische Schule mit der Anrede Israels als 'Söhnen Jahwes' (14.1)”.

11 Betreffende hierdie verhouding konkludeer Beuken (2003:70) soos volg: "Die Metapher »Söhne« (geschlechtsneutral für »Kinder«) wird im Jesajabuch ebenso spärlich für das Verhältnis von Israel zu JHWH gebraucht (Jes 30,1.9; 43,6; 45,11; vgl. Ex 4,23; Dtn 32,5; Jer 31,9; Hos 11,1) wie die Metapher »Vater« für die Beziehung von JHWH zu Israel (Jes 63,16; 64,7; vgl. Dtn 32,6.18; Jer 3,4; Ps 103,13). Beide Metaphern deuten auf eine natürliche Verbundenheit zwischen JHWH und Israel hin: Der Ursprung des Volkes liegt in Gott".

12 Vgl Wolff (1976:257) met betrekking tot hierdie teks: "Nachdem Hoseas polemische Theologie einmal das frühe Israel als legitimen Sohn Jahwes denken konnte ... bildet er die Metapher frei aus, angeregt vor allem durch die Traditionen aus der Geschichte Israels".

13 Wildenberger (1972:12) konkludeer soos volg: “... Güte Gottes, die unter dem Bild der Fürsorglichkeit eines Vaters zur Darstellung kommt". 
Jahwe vir Israel 'n vader is. Volgens Psalm 103:13 is hy 'n vader wat Hom oor sy kinders ontferm (vgl Zenger 1997a:419-422). As vader sien Hy in sy groot liefde en genade na Israel (sy volk/kinders) om (Jes 63:7-16 ${ }^{15}$; vgl ook Jes 43:6; 64:8; Hos 11:1; Mal 3:17). G’n wonder oud-Israel het Jahwe beskryf as die Een wat barmhartig en genadig is, lankmoedig, vol liefde en trou. Hy betoon sy onmeetlike liefde aan sy volk (Eks 34:6-7) ${ }^{16}$.

\section{JAHWE AS VROU / MOEDER}

Dit is opvallend (verbasend) dat hierdie idee vir baie lank deur die meerderheid (manlike) teoloë geïgnoreer is ${ }^{17}$. In hierdie verband het die feministiese eksegese ' $n$ baie belangrike korrektief gebring op 'n eensydige (manlike) perspektief ${ }^{18}$. Soos reeds opgemerk, in die

14 Wat Jer 31:9 betref, postuleer Fischer (2005:151) soos volg: "Gottes tun gründet (>denn $)$ in seiner engen personalen Bindung an das Volk, für die nächste Verwandtschaftsverhältnisse stehen (>Vater, Erstgeborener` nicht real, sondern bildhaft für gewählte Nähe und Verpflichtung). Die Aussage Gottes »ich werde ihm Vater sein « geht zurück auf 2 Sam 7,14 ..., das David bezüglich seines Sohnes gegebene Versprechen (mehrfach aufgenommen in $1 \mathrm{Chr}$ 17,33; $22,10 ; 28,6)$. Jene Verheißung ist jetzt ausgedehnt auf >Israel<, das ganze Volk ... hebt Gott den Aspekt der besonderen, auswählenden und unverdienten Zuwendung ... hervor und steigert sie zum höchsten Maß".

15 Vgl Kaiser (1981:30): “Und wenn Jahwe nach der uns zur Verfügung stehenden Überlieferung erstmals in Jes 63,16 als 'unser Vater' angesprochen wird, ist dabei an sein Eintreten als Rechtshelfer für Israel gedacht, der sein geknechtetes Volk wie Waisen vertritt".

16 Vgl ook Dohmen 2004:354-355; Scoralick 2002:35vv en Te Stroete 1966:231.

17 In hierdie verband konkludeer Staubli \& Schroer (2001:72) soos volg: "But although the concept had a central place in the biblical image of the human, many male biblical scholars and theologians have completely ignored it. It was only with the advent of feminist biblical exegesis that this gap in patriarchal education was partially filled".

18 Schottroff, Schroer \& Wacker (1998:40) maak die volgende opmerking: "Aangezien de christelijke theologie bij ons nog niet zo lang geleden de facto een aangelegenheid van mannen was, aangezien het priesterambt binnen de katholieke kerk de jure aan de (ongetrouwde) man is voorbehouden, en aangezien de filosofisch-theologische uitleg van het Woord Gods talloze clichés over manlijkheid en vrouwelijkheid bevat die het mondige menszijn van vrouwen tegenwerken, kan het feminisme of de feministische wetenschap zich niet onkritisch-affirmatief verhouden tot de christelijke theologie en de 
praktyk was die realiteit van oud-Israel gekenmerk deur 'n oorwegende patriargale kultuur ${ }^{19}$.

Ten spyte hiervan is dit verrassend - ja, ' $n$ mens sou selfs kon sê eintlik selfs bietjie teenstrydig hiermee - dat ons in verskillende boeke in aanraking kom met voorstellings van Jahwe wat geskets word as vrou en as moeder (dws met vroulike asook moederlike karaktertrekke). Hierdeur word Jahwe voorgestel as 'n sagte God, dit wil sê 'n God wat barmhartig en vol begrip is, wat medelye het ${ }^{20}$.

kerkelijk-gemeentelijke praxis". Vgl ook Fischer 2002:16vv en Klopper 2002:422vv.

19 Betreffende hierdie aspek van die Ou-Testamentiese ontstaansgeskiedenis konkludeer Fischer (1997:176) soos volg: "Die Bibel ist in einer partriarchal strukturierten Gesellschaft verfaßt worden, in welcher freie Männer von höherem Sozialstatus Macht über Frauen und Kinder sowie über sozial niedriger gestellte Geschlechtsgenossen hatten, wobei Frauen jeweils unter den Männern derselben Schicht rangierten. Und die Bibel ist vorrangig von Männern für Männer geschrieben worden. $\mathrm{Da} \beta$ diese ihre androzentrische Perspektive eintrugen, ist selbstverständlich. Denn die Texte der Bibel wollen Menschen einer bestimmten Zeit und Situation etwas sagen und sind daher aus einem konkreten gesellschaftlichen Kontext und für diesen geschrieben worden".

20 In hierdie verband konkludeer Haag \& Elliger (1999:36) soos volg: "Um so erstaunlicher, ja geradezu widersprüchlicher ist es, da $\beta$ vor allem bei den Propheten genau dieser Jahwe mütterlicher und fraulicher Züge annimmt, barmherzig und verständnisvoll, mitleidend und sanft erscheint". Scoralick (2002:4) merk ook soos volg op: "Seit der bahnbrechende Untersuchung von Phyllis Trible richtet sich eine der Hoffnungen feministischer Exegetinnen auf biblische begründetes, frauenebefreiendes (oder zumindest nicht-androzentrisches) Sprechen von Gott auf die Charakterisierung JHWHs als 'barmherzig' (rehem), da in dem hebräischen Wort noch als Hintergrundmetapher die Bezeichnung für 'Mutterscho $\beta$ ' mitschwinge und somit weibliche Züge im Gottesbild vertreten seien". In hierdie verband merk Groenewald (2006:52) soos volg op: "Daar is alreeds gewys op die feit dat die rehem (die baarmoeder) die setel van kragtige emosies is. Verwant aan hierdie woord, is die woord rahamim wat onder andere "medelye", "deernis", "simpatie" aandui. Rahamim gee verder ook uitdrukking aan die moederlike liefde: dit lyk dus asof medelye en simpatie hulle oorsprong in die baarmoeder het; daarom is dit veral die vrou wat oor die vermoëns beskik om hierdie emosies op te wek. Opvallend is egter die feit dat Jahwe (die God van Israel) voortdurend oorval word deur rahamim (simpatie, deernis/medelye, liefde) wanneer daar in verskillende tekste gepraat word oor sy verhouding tot sy volk Israel". 
Hier word nou na 'n paar voorbeelde verwys as illustrasie van die voorafgaande stelling. Ons sou eerste kon wys op die teologie van daardie gedeelte van die boek Jesaja wat tradisioneel met die ballingskap in verband gebring word, naamlik Deutero-Jesaja (4055). Die teoloë verantwoordelik vir hierdie gedeelte kondig in troosryke woorde ' $n$ nuwe begin in die verhouding tussen Israel en Jahwe aan. Opvallend is veral die feit dat ons in hierdie gedeelte van die boek Jesaja tekste aantref waarin beelde vir Jahwe gebruik word wat ontleen is aan die ervaringswêreld van vroue (Schottroff, Schroer \& Wacker 1998:141). In Jesaja 42:14 word van Jahwe gesê dat Sy swanger is ${ }^{21}$. As ons verder lees in die boek Jesaja word Sy (Jahwe) vergelyk met 'n vrou wat haar ontferm oor hierdie kind wat Sy (hierdie vrou) in die lewe gebring het. Die kind se naam is in Haar handpalms gegraveer (Jes 49:15-16) ${ }^{22}$.

In Jesaja 66:13 word Sy voorgestel as die beskermende moeder, die moeder wat haar volk veilig laat voel ${ }^{23 .}$ Verder kan ook gewys word op die uitdrukking "grootmaak", waarin blyk dat 'n moederlike nuanse in die Israelitiese godsbeeld opgesluit is (vgl oa Jes 1:2; 23:4;

21 Dit is interessant om te wys op die volgende opmerking van Koole (1985:177) in hierdie verband: "De Targum schrikt ervoor terug dat God zich zou vergelijken met een barende vrouw en denkt aan die weeën van het gericht over de verlaters van de wet. Meer aandacht verdienen die opmerkingen van CALVIJN en FOREIRO, dat God niet alleen de Krijgsman maar ook de Moeder is, 49:15; 66:13"'. Vgl ook Beuken 1986:146.

22 In hierdie verband merk Beuken (1983:56) soos volg op: "In de twee volgende regels al vergelijkt YHWH zijn ontferming over Israël met de zorg van een vrouw voor haar kind". Vgl verder ook Watts (1987:189): "Yahweh emphasizes his continued concern and compassion by using a comparison with a nursing mother ..."; asook Berges (1998:373): "Die Adressatin van 49,14-26 ist durchgehend Zion, die kinder- und zukunftslose Frau, der Nachkommenschaft verheißen ist. Der Ebed qua heimgehehrter Gola, der selbst den Weg vom Zweifel zur Erkenntnis der Heilsmächtigkeit JHWHs gegangen war, bestreitet der Jerusalemer Stadtbevölkerung zwar nicht das Recht auf Klage, wohl aber das des hoffnungstötenden Festhaltens an ihr. Auf die Klage, von JHWH vergessen worden zu sein, antwortet der Ebed mit der rhetorischen Frage, wie denn eine Mutter ihr Baby vergessen könne; und selbst wenn das möglich sein sollte, JHWH werde Zion nie vergessen $(49,15)$ ".

23 Vlg Schottroff, Schroer \& Wacker (1998:142) is "de boodschap van Trito-Jesaja voor die armen [is] vol troost. Ook deze dicht bij het volk staande missionarissen van JHWH kennen sowel mannen als vrouwen een plaats toe in hun religieuze taal, spreken van God als moeder $(66,13)$ of betrouwbare vader". 
49:21; 51:18) ${ }^{24 .}$ In Psalm 22:10 word God (Jahwe) voorgestel deur middel van die beeld van 'n vroedvrou. Sy is die een wat die moeder bystaan by die geboorte van die kind ${ }^{25}$. Dit is ook moontlik om na Hosea 11 te verwys: volgens hierdie teks vertoon God beide vaderlike $^{26}$ en moederlike karaktertrekke (Zenger 1995a:79) ${ }^{27}$. Wat betref die skoonheid van byvoorbeeld vers 8, merk Macintosh (1997:460) soos volg op: "greatest in Hosea - deepest if not highest of his book - the breaking forth of that inexhaustible mercy of the Most High".

Van Jahwe word ook in die boek Jesaja (31:5) die beeld gebruik dat Sy, soos voëls beskermend oor hulle neste fladder, 'n skild oor Jerusalem sal wees - Sy sal dus beskerm en beskut (Watts 1985:409) ${ }^{28}$. Die lang gedig wat in Deuteronomium 32 voorkom, bevat ook uitsprake wat dui op moederlike (versorgende) aspekte van God (Labuschagne 1997:234-237). So byvoorbeeld word gesê dat Jahwe Israel versorg soos haar oogappel ( $\mathrm{v} 10$ ). In die daaropvolgende verse kry ons die aangrypende mooi beeld waarin

24 Beuken (2003:70) postuleer soos volg: "Dabei bringen die Ausdrücke "großziehen« und »emporbringen« eine mütterliche Nuance in das Bild Gottes hinein".

25 "Der Beter erinnert Gott an die persönliche Verbindung von Anfang an. Gott übernimmt hier die singuläre Roller einer Hebamme" (Hossfeld \& Zenger 1993:149).

26 Vgl in hierdie verband Wolff (1976:255) se opmerking: "Die Liebe zu dem hilflosen jungen Israel erwies sich nicht nur darin, da $\beta$ er ihn aus Ägypten herausführte, sondern da $\beta$ er ihn damit zugleich 'rief', wie ein Vater 'seinen Sohn' ruft ... Daß Israel hier 'Sohn' Jahwes hei $\beta$ t, unterstreicht das in 1a und in 3f. ausgeführte persönliche Liebesverhältnis. Israel soll aufs engste und unlöslich seinem Gott verbunden sein".

27 Wat betref hierdie gedeelte uit Hosea, maak Zenger (1995a:81) die volgende opmerking: "Aber da ist eben auch, wie Hosea sagt, eine weiblichemütterliche Seite in Gott - Gott hat gewissermaßen einen Mutterscho $\beta$-, und diese weibliche-mütterliche Seite setzt sich durch und macht deutlich: Gottes bedingunslose Liebe mu $\beta$ sich gerade im Augenblick der Schuld erweisen - als Liebe, die geduldig wartet und zu ihren Kindern steht. Der biblische Gott will nicht den Tod, sondern das Leben seiner Kinder".

28 Kaiser (1983:252) het in hierdie verband soos volg opgemerk: "Der Dichter will uns sagen, da $\beta$ Jahwe den Zion so beschützen wird, wie die über ihren Nestern hin und her flatternden Vögel ihre Brut verteidigen, vgl. 5. Mose 32,11 und Ps. 91,4". 
Jahwe vergelyk word met 'n arend. Sy is soos 'n arend wat waghou oor haar nes, oor haar kleintjies sweef, haar vlerke uitsprei, hulle optel uit die nes en die kuikens op haar vlerke dra. Op dieselfde wyse het Jahwe sy volk gelei, versorg en gevoed (vv 11-14). Sy is ook die Een van wie gesê word dat Sy mense wat op haar vertrou onder haar vlerke (vleuels) inneem en versorg (vgl oa Pss 17:8; 36:8; 61:5; 63:8; 91:4; Rut 2:12).

\section{SLOTOPMERKINGS}

Hierdie kort oorsig van ' $\mathrm{n}$ aantal (liefdes-)tekste in die Eerste Testament bied vir ons ' $\mathrm{n}$ kyk (in 'n neutedop) op die skoonheid en diepte van hierdie Boek(e). Die kort oorsig oor die tekste waarin twee aspekte van die Godsbeeld(e) van oud-Israel na vore kom, naamlik tekste waarin na (liefdevolle) vaderlike en moederlike (vroulike) karaktertrekke van Jahwe verwys word, lewer bewys van die feit dat hierdie Marcionitiese vooroordele teen die Eerste Testament ongeoorloof is. In die lees van hierdie beelde word ons oorspoel deur die liefde wat Jahwe aan sy volk betoon.

Waarvoor ek hier wil pleit is dat dit weer tyd is dat ons as Christene opnuut sal leer om die Eerste Testament as onlosmaaklike en kosbare deel van ons Bybel te hoor, te lees en daarmee erns te maak. Die Kerk het in ieder geval vanaf sy eerste treë dit duidelik gemaak dat hy kies om die Eerste Testament as deel van sy tweeledige Bybel te behou; die Kerk het dit dus in beide teorie en praktyk bevestig dat hy die Ou Testament nodig het. Dit is daarom ook weereens nodig dat aan hierdie keuse inhoud gegee moet word $^{29}$. Hierin het ons ' $n$ hulp vir die lewe: lewenshulp wat ons nie

29 In sy afskeidsrede het Herbert Haag (1980:304v) die noodsaaklikheid van die Ou Testament vir die Kerk soos volg verwoord: "Das Festhalten der Kirche am Alten Testament ist nur dann gerechtfertigt, wenn dieses gegenüber dem Neuen Testament ein Plus aufweist: wenn es große und unentbehrliche Themen behandelt, die im Neuen Testament fehlen; wenn es dem Menschen eine Lebenshilfe anbietet, die das Neue Testament ihm nicht geben kann. Wir haben wohl insgesamt in unserem Umgang mit der Bibel den Fehler begangen, da $\beta$ wir sie zu einseitig als Offenbarungsquelle und als religiöses Lehrbuch betractet haben, während sie doch zunächst einen Spiegel des Lebens mit seinen Höhen und Tiefen darstellt und dem Menschen in seiner Verlorenheit von Gott her Orientierung und Hilfe sein will. Dann aber benötigt die Kirche neben dem Neuen Testament als dem Buch von Christus ebenso dringend das Alte Testament als das Buch von Gott und Menschen". 
altyd op sodanige wyse in die Tweede Testament (Nuwe) aantref nie (Zenger 1994:9). In vele opsigte is die perspektiewe wat die Eerste Testament ons bied, "n noodsaaklike aanvulling tot die Tweede Testament. Teenoor die Tweede fokus die Eerste veel meer op die mens en sy/haar alledaagse lewe ${ }^{30}$. Waar die Tweede hoofsaaklik Christus-gesentreerd is, kan ons sê die Eerste is die boek van God, die wêreld en van die mense. Ten slotte wil ek aansluit by die idee van die bekende Duitse Ou-Testamentikus Erich Zenger (1994:52): "Da $\beta$ die Bibel sowohl in literarischer wie in inhaltlicher Hinsicht ein ungewöhnliches Mischgebilde ist, wird von denen, die sie lesen und lieben, meist mit großer Bewunderung wahrgenommen. Die Vielfalt der einzelnen biblischen Schriften zeichnet sowohl das Erste (»Alte«) Testament wie das Zweite (»Neue«) Testament aus, auch wenn die Vielfalt des Ersten Testaments (angesichts des viel größeren Umfangs, angesichts der komplexeren Lebenswirklichkeit, die da zur Sprache kommt, und angesichts des viel größeren Zeitraums seiner Entstehung) gegenüber dem »kleinen« Neuen Testament natürlich viel imponierender ist".

Hopelik het hierdie bydrae iets ontsluit van die fassinerende wêreld wat opgesluit is in die tekste van die Hebreeuse Bybel. Hopelik

30 Vgl in hierdie verband Gro $\beta$ \& Kuschel (1992:58v): "Das Neue Testament wurde innerhalb weniger Jahrzehnte verfa $\beta t$, es spiegelt daher nur eine relative kurze Bewährungsprobe und eine eng begrenzte Vielfalt von Versuchen, aus den neuen Glaubensinhalten zu leben; die Christen bildeten in ihrer jeweiligen Gesellschaft eine verschwindende Minderheit, die Gefährdungen wie die Chancen einer mit Staat und Gesellschaft verwobenen Staatsreligion liegen noch völlig außerhalb seines Geschichtskreises. Das Alte Testament entstand dagegen in einer sehr wechselvollen vielhundertjährigen Geschichte; Theologumena kamen und gingen; das Scheitern leitender theologischer Konzeptionen und ehemals bedeutsamer Gottesbilder, so auch das Scheitern mancher theologischer Theorien über das unverschuldete Leiden wurden erkannt und ausformuliert, und dies ging in Gestalt jüngerer Texte wiederum in das Alte Testament ein, erhöht seine Komplexität, bewahrte seine Lebensnähe. Umfaßte das Neue Testament eine vergleichbare Entstehungszeit, so wäre es unter Karl dem Großen noch nicht abgeschlossen gewesen. Der Zusammenbruch des Römischen Reiches, die Schrecken der Völkerwanderungszeit, die ja tatsächlich theologische Erdbeben erzeugten, hätten u.a. Spuren der durch sie erzwungenen theologischen Reflexion im Neuen Testament selbst hinterlassen, so auch dessen Komplexität und Lebensnähe stärken können. Das war durch den frühen Abschlu $\beta$ des neutestamentlichen Kanons unmöglich”. 
ontwikkel daar ' $n$ fassinasie met, en ' $n$ liefde vir die Eerste - daardie Boek(e) waarin ons Jahwe leer ken as beide die liefdevolle vader en die liefdevolle moeder. Dit sal egter alleenlik kan gebeur wanneer ons ons in groot respek, verwondering en in voortdurende studie daaraan wy. Dan sal dit ook vir ons moontlik wees om saam met die digter van Psalm 119 die volgende te kan uitroep:

"Hoe lief het ek die Eerste Testament,

dit bly my elke oomblik by,

dit gee my meer insig,

dit is vir my aangenaam,

soeter as heuning in die mond" (Ps 119:97-103 - aangepas).

\section{Literatuurverwysings}

Berges, U 1998. Das Buch Jesaja - Komposition und Endgestalt. Freiburg i.B.: Herder (HBS 16).

Beuken, W A M 1983. Jesaja deel II-B. Nijkerk: Callenbach (POT).

-, ${ }^{2}$ 1986. Jesaja deel II-A. Nijkerk: Callenbach (POT).

-, 2003. Jesaja 1-12. Freiburg i.B.: Herder (HThKAT).

Den Heyer, C J ${ }^{2}$ 1995. Een Bijbel - twee testamenten. De plaats van Israël in een Bijbelse theologie. Kampen: Kok (Verkenning en Bezinning 1).

Dohmen, Chr 2004. Exodus 19-40. Freiburg i.B.: Herder (HThKAT).

Fischer, G 2005. Jeremia 26-52. Freiburg i.B.: Herder (HThKAT).

Fischer, I 1997. Das Alte Testament - ein Buch für Frauen?, in: Zenger, E (Hrsg.), Lebendige Welt der Bibel. Entdeckungsreise in das Alte Testament, 176-183. Freiburg i.B.: Herder.

-, 2002. Gotteskünderinnen. Zu einer geschlechterfairen Deutung des Phänomens der Prophetie und der Prophetinnen in der Hebräischen Bibel. Stuttgart: Kohlhammer.

Gese, H 1995. Über die biblische Einheit, in: Dohmen, Ch \& Söding, Th (Hrsg.), Eine Bibel - zwei Testamente, 35-44. Paderborn: Ferdinand Schöningh (UTB 1893).

Gunneweg, A H J 1977. Vom Verstehen des Alten Testaments. Eine Hermeneutik. Göttingen: Vandenhoeck \& Ruprecht (ATD Ergängzungsreihe $5)$.

Groenewald, A 2006. Drink met vreugde uit die liefdesfontein! 'n OuTestamentiese perspektief op menslike seksualiteit. Verbum et Ecclesia 27/1: 42-69.

Groß, W \& Kuschel, K-J 1992. "Ich schaffe Finsternis und Unheil!" Ist Gott verantwortlich für das Übel? Mainz: Matthias-Grünewald. 
Haag, H 1980. Das Buch des Bundes: Aufsätze zur Bibel und zu ihrer Welt. Düsseldorf: Patmos-Verlag.

Haag, H \& Elliger, K ${ }^{2}$ 1999. Zur Liebe befreit. Sexualität in der Bibel und heute. Zürich/Düsseldorf: Benziger Verlag.

Hossfeld, F-L \& Zenger, E 1993. Die Psalmen I. Psalm 1-50. Würzburg: Echter Verlag (NEB 29).

Kaiser, O 1981. Das Buch des Propheten Jesaja. Kapitel 1-12. Göttingen: Vandenhoeck \& Ruprecht (ATD 17).

-, 1983. Der Prophet Jesaja. Kapitel 13-39. Göttingen: Vandenhoeck \& Ruprecht (ATD 18).

-, 1995. Die Botschaft der beiden Testamenten, in: Dohmen, Ch \& Söding, Th (Hrsg.), Eine Bibel - zwei Testamente, 45-58. Paderborn: Ferdinand Schöningh (UTB 1893).

Klopper, F 2002. Women, monotheism and the gender of God. In die Skriflig 36/3: 421-437.

Koole, J L 1985. Jesaja II. Deel I: Jesaja 40 t/m 48. Kampen: J H Kok (COT).

Labuschagne, C J 1997. Deuteronomium deel II. Baarn: Callenbach (POT).

Le Roux, J H 2003. Von Harnack, Marcion en die Ou Testament. Verbum et Ecclesia 24/1: 124-136.

Lohfink, N 1995. Eine Bibel - zwei Testamente, in: Dohmen, Ch \& Söding, Th (Hrsg.), Eine Bibel - zwei Testamente, 71-81. Paderborn: Ferdinand Schöningh (UTB 1893).

Macintosh, A A 1997. Hosea. Edinburgh: T\&T Clark (ICC).

Rendtorff, R 1995. Die Bibel Israels als Buch der Christen, in: Dohmen, Chr \& Söding, Th (Hrsg.), Eine Bibel - zwei Testamente, 97-113. Paderborn: Ferdinand Schöningh (UTB 1893).

Reventlow. H G 1995. Zwischen Bundestheologie und Christologie. Überlegungen eines christlichen Alttestamentlers zur Biblischen Theologie, in: Dohmen, Ch \& Söding, Th (Hrsg.), Eine Bibel - zwei Testamente, 115-130. Paderborn: Ferdinand Schöningh (UTB 1893).

Schottroff, L, Schroer, S \& Wacker, M-T 1998. Bijbel in vrouwelijk perspectief. Baarn: Ten Have (vertaal uit die oorspronklike Duits: 1995. Feministische Exegese. Darmstadt: WBG).

Scoralick, R 2002. Gottes Güte und Gottes Zorn. Die Gottesprädikationen in Ex 34,6f und ihre intertextuellen Beziehungen zum Zwölfprophetenbuch. Freiburg i.B.: Herder (HBS 33).

Seebass, H 1995. Über die innere Einheit von Altem und Neuem Testament, in: Dohmen, Ch \& Söding, Th (Hrsg.), Eine Bibel - zwei Testamente, 131-142. Paderborn: Ferdinand Schöningh (UTB 1893). 
Staubli, Th \& Schroer, S 2001. Body symbolism in the Bible. Collegeville, Minnesota: The Liturgical Press (vertaal deur L M Maloney uit die oorspronklike Duits: 1998. Körpersymbolik der Bibel. Darmstadt: WBG).

Te Stroete, G 1966. Exodus. Roermond: J J Romen \& Zonen (BOT).

Von Harnack, A 1996 (Nachdruck ${ }^{2}$ 1924). Marcion. Das Evangelium vom fremden Gott. Eine Monographie zur Geschichte der Grundlegung der katholischen Kirche. Neue Studien zu Marcion. Darmstadt: WBG (Bibliothek Klassischer Texte).

Vorster, J N 2003. Wat sê die Bybel regtig oor ... God? Pretoria: CB Powell Bybelsentrum (Unisa).

Watts, J D W 1985. Isaiah 1-33. Waco, Texas: Word Book Publisher (WBC 24).

-, 1987. Isaiah 34-66. Waco, Texas: Word Book Publisher (WBC 25).

Wildenberger, H 1972. Jesaja. Kapitel 1-12. Neukirchen-Vluyn: Neukirchener Verlag (BKAT X/1).

Wolff, H-W ${ }^{3}$ 1976. Hosea. Neukirchen-Vluyn: Neukirchener Verlag. (BKAT $\mathrm{XIV} / 1)$.

Zenger, E ${ }^{2}$ 1994. Am Fuss des Sinai. Gottesbilder des Ersten Testaments. Düsseldorf: Patmos.

-, ${ }^{5}$ 1995a. Das Erste Testament. Die jüdische Bibel und die Christen. Düsseldorf: Patmos.

-, 1995b. Thesen zu einer Hermeneutik des Ersten Testaments nach Auschwitz, in: Dohmen, Ch \& Söding, Th (Hrsg.), Eine Bibel - zwei Testamente, 143-158. Paderborn: Ferdinand Schöningh (UTB 1893).

-, 1997a. Die Nacht wird leuchten wie der Tag. Psalmenauslegungen. Freiburg i.B.: Herder.

-, 1997b. Gemeinsame Bibel für Juden und Christen, in: Zenger, E (Hrsg.), Lebendige Welt der Bibel. Entdeckungsreise in das Alte Testament, 184-191. Freiburg i.B.: Herder.

-, ${ }^{5} 2004$. Heilige Schrift der Juden und der Christen, in: Zenger, E (Hrsg.), Einleitung in das Alte Testament, 11-33. Stuttgart: Kohlhammer (STh 1). 